SYMBOLAE PHILOLOGORUM POSNANIENSIUM GRAECAE ET LATINAE XXVII/1 • 2017

pp. 93-101. ISSN 0302-7384

DOI: $10.14746 /$ sppgl.2017.XXVII.1.7

MONIKA SZCZOT

Instytut Filologii Polskiej, Uniwersytet im. Adama Mickiewicza w Poznaniu

ul. Fredry 10, 61-701 Poznań

Polska - Poland

\title{
SATYRA, ROZMOWA ZMARŁYCH CZY DIALOG POLITYCZNY? \\ O FORMIE GATUNKOWEJ UTWORU KLEMENSA JANICKIEGO IN POLONICI VESTITUS VARIETATEM ET INCONSTANTIAM DIALOGUS
}

\begin{abstract}
Szczot Monika, Satyra, rozmowa zmarlych czy dialog polityczny? O formie gatunkowej utworu Klemensa Janickiego „In Polonici vestitus varietatem et inconstantiam dialogus” (A satire, a dialogue of the dead or a political dialogue? About the genre form of a literary piece by Klemens Janicki entitled In Polonici vestitus varietatem et inconstantiam dialogus).
\end{abstract}

The articles focuses on the analysis of the genology of a literary piece by Klemens Janicki. Its form turns out to be of complex and syncretic nature, likewise the issues discussed therein and concerning the politics and social manners.

Keywords: satire; dialogue of the dead; political dialogue.

Powstanie utworu Klemensa Janickiego In Polonici vestitus varietatem et inconstantiam dialogus datowane jest na koniec roku 1541 lub początek 1542, i chociaż drukiem został on ogłoszony dopiero w 1563 roku, to, jak podkreśla Ludwik Ćwikliński, w manuskryptach tekst rozszedł się już na początku lat czterdziestych i inspirował Bellum Theologicum Andrzeja Lubelczyka ${ }^{1}$. Utwór powstał jako odpowiedź na trudną sytuację polityczną w Europie, znajdującej się wobec realnego zagrożenia tureckiego ${ }^{2}$. Chodzi tu o podboje Solimana Wspaniałego, panującego w latach 1520-1566; to właśnie on zorganizował w latach 1526-1543 pięć dużych wypraw wojennych na Węgry. W roku 1529 Turcy oblegali Wiedeń, a chrześcijańska Europa próbowała jednoczyć się przeciwko nim pod patronatem kolejnych papieży: Juliusza II, Leona X i Klemensa VII. Zygmunt Stary starał się zachować neutralność wobec konfliktu habsburskotureckiego, prowadząc politykę antyhabsburską i utrzymując pokojowe stosunki

${ }^{1}$ Vide Ćwikliński 1934: 6-9.

${ }^{2}$ Jako dialog polityczny czyta i analizuje ten utwór Nowak-Dłużewski (1966: 101-102), umieszczając go wśród antytureckich utworów innych autorów. 
z Turcją dzięki rozejmowi, a potem traktatowi wieczystemu z 1533 r. W 1541 roku Soliman pokonał wojska Ferdynanda i zdobył Budę. Jan Zygmunt - wnuk Zygmunta Starego - został uznany przez Turcję za księcia siedmiogrodzkiego. Takie jest ogólne i przedstawione w skrócie tło historyczne, niezbędne do zrozumienia jednej z turcyk napisanej przez Klemensa Janickiego. Problem podboju tureckiego pojawia się także w elegiach; poeta wypowiada się w nich na temat spraw tureckich i wołoskich: chodzi tu o elegie 6, 8 i 9 ze zbioru Tristia i elegie 7 i 10 z Variae elegiae. Na tle liryków dialog jest najobszerniejszą turcyką Janickiego, chociaż treści polityczne ulegają w niej ściszeniu na rzecz satyry.

Historyczna lektura tekstu literackiego, proponowana niegdyś przez Michała Głowińskiego, zakłada mimetyczny styl lektury, pozwalający na odtworzenie faktów opisywanych przez dzieło literackie ${ }^{3}$. Tekst jest dokumentem swoich czasów i rozpatrywany na tle szerszego kontekstu nabiera swoistych znaczeń. Można jednak powiedzieć, że konwencja literacka pozwala się czytać na dwa sposoby i dla dwóch celów: jako dokument historycznego stanu świadomości swoich czasów albo (i) jako utrudnienie w dotarciu do kluczowych dla tekstu zdarzeń historycznych. Chyba z obiema tendencjami mamy do czynienia w utworze Janickiego: sytuacja wyjściowa utworu jest jasna, zresztą była ona wielokrotnie omawiana w opracowaniach. Dialog powstaje jako bezpośrednia reakcja na wspominane wcześniej niebezpieczeństwo grożące Europie i Polsce ze strony Turcji.

\section{R.: Pannonas et Valachos devicit Turca, propinqua est, Ut video, Regno maxima flamma meo. \\ Surgo igitur tumulo, rebus si forte meorum Consilio aut alia subveniamus ope (w. $1-4$, s. 248$)^{4}$.}

Kolejny fakt historyczny to rządy dwóch królów: Zygmunta Starego i Zygmunta Augusta oraz wspominany już tutaj traktat wieczysty z Turcją, dla którego ,zmartwychwstały” Król Jagiełło wyraża dezaprobatę:
R.: (...) Utrique
Sunt sacra cum Turcis foedera, nulla mihi.
S.: Foedera? Sed taceo!
(w. 15-17, s. 250)

To co wydaje się oczywiste dla Króla, nie jest już tak oczywiste dla Stańczyka, zanurzonego we współczesności i polityce króla (królów). Przymierze

\footnotetext{
${ }^{3}$ Inspirujące dla tego artykułu rozważania na temat czytania utworu literackiego jako źródła historycznego, vide Głowiński 1978: 94-113.

${ }^{4}$ Dialog Klemensa Janickiego cytuję w artykule według wydania: Janicki 1966. Przy cytacie podaję numer wersu i stronicy.
} 
z Turcją było odpowiedzią Polski na rosnące wpływy Habsburgów w Europie. Ten znak zapytania przy słowie foedera to właśnie zaciemnienie czy utrudnienie w literackim przedstawianiu polskiej sytuacji politycznej, którą rzeczywiście nie zawsze można było jednoznacznie ocenić. Jagiełło reprezentuje stronnictwo antytureckie, więc odrzuca układy z Turcją. Stańczyk wchodzi w rolę rozważnego polityka: na pewne tematy lepiej i bezpieczniej milczeć ${ }^{5}$, dlatego przeniesienie środka ciężkości dialogu z ważkich tematów politycznych na sferę obyczajową sprawia rozmówcom widoczną ulgę, zwalnia z kłopotliwych niedopowiedzeń czy przemilczeń i daje pole do popisów w zakresie obserwacji XVI-wiecznej rzeczywistości. Dialog Janickiego to z jednej strony świadectwo historyczne swoich czasów (przynosi pewną wiedzę historyczno-polityczną), a z drugiej strony może być on także współczynnikiem procesu historycznoliterackiego, a nawet dziejowego ${ }^{6}$, czyli można odnotować oddziaływanie dialogu na powstanie utworów późniejszych ${ }^{7}$, ale także (co zapewne bardziej skomplikowane i trudniejsze) pokazać rolę historyczną samego utworu. Michał Głowiński ujął to bardzo trafnie w swoich rozważaniach:

Chodziłoby tu więc o czytanie dzieła jako zamierzonego oddziaływania, jako wskazówki wobec współczesnych, jak mają się w życiu społecznym zachowywać. Tego, czy zamierzone oddziaływania stały się oddziaływaniami rzeczywistymi, z samych utworów już odczytać nie można, potrzebne są po temu inne świadectwa ${ }^{8}$.

Można wpisać utwór Janickiego w cały nurt poezji polsko-łacińskiej traktującej Polskę jako przedmurze chrześcijaństwa. Poezja ta przybierała charakter publicystyczny, była nastawiona na wytwarzanie specyficznej atmosfery politycznej i pomagała odbiorcom w wydawaniu sądów o rzeczywistości. Pisane na okoliczność utwory żywo reagowały na aktualne wydarzenia, kształtowały opinię czytelników, stawały się wzorcami postaw i zachowań. Można więc sformułować ostrożny wniosek, podążając za sugestią Marii Cytowskiej, że napisany dystychem elegijnym dialog Janickiego łatwiej trafiał do wyobraźni i uczuć odbiorców niż dzieła prozaików9.

Dominująca w utworze tendencja satyryczna odrzuca ostatecznie agresywność i inwektywę na rzecz ogólnej krytyki wad społeczno-obyczajowych. Dialog przybiera formę barwnej scenki rodzajowej, realizującej założone cele moralne i wartości humanistyczne; w pewnym sensie możemy mówić o zamierzonym

${ }^{5}$ Utrzymanie pokoju z Turcją nie było łatwe i wymagało dużego kunsztu dyplomatycznego, vide Pajewski 1997: 51.

${ }^{6}$ Cf. Głowiński 1978: 111.

${ }^{7} \mathrm{O}$ oddziaływaniu utworu K. Janickiego na twórczość Andrzeja Lubelczyka, vide Ćwikliński 1934: 6-9. Utwór K. Janickiego miał znać również Mikołaj Rej, vide Krzyżanowski 1954: 179-184.

${ }^{8}$ Głowiński 1978: 111.

${ }^{9} \mathrm{O}$ aktualnej i publicystycznej roli poezji polsko-łacińskiej, vide Cytowska 1993: 59-68. 
psychagogicznym oddziaływaniu na morale odbiorców, których chce się przemienić w patriotów wiernych obyczajom przodków. Odkrywamy w utworze komizm charakterystyczny dla satyry, który oscyluje między wzniosłością a prostotą, powagą a żartem. Przydatna w jego odczytaniu mogłaby się zapewne okazać kategoria spoudaiogéloion, przedstawiona w Ars poetica Horacego i realizowana w satyrach Wenuzyjczyka ${ }^{10}$. Janicki, podobnie jak Horacy, ścisza inwektywę, stara się zachować równowagę estetyczną między géloion i spoudaion, posługuje się śmiechem i mądrą ironią, a forma dialogu pomaga w pełnym odzwierciedleniu wspomnianych elementów. Dążenie do etycznego (i estetycznego?) decorum $^{11} \mathrm{w}$ utworze Janickiego widać już w doborze rozmówców dialogu: pomiędzy królem a błaznem istnieje różnica w statusie społecznym, ale przewrotnie te dwie postaci uzupełniają się i stają się komplementarne. Antagonizm postaci pozwala nie tylko wyraźniej (czytaj: odważniej) pokazać rzeczywistość, lecz także oceniać ją z różnych punktów widzenia. Dialogowe starcie, które proponuje Janicki to starcie przesycone satyrą i ironią o różnym nasileniu i charakterze, bo interlokutorzy nie walczą ze sobą, broniąc każdy swoich racji; obaj mają jeden cel, ale każdy realizuje go inaczej, wzbogacając estetycznie przestrzeń utworu. Błazen jest komicznym dublerem władcy, jego przebiegłość, spryt i inteligencja służą parodiowaniu i podważaniu poważnych kwestii wypowiadanych przez szacownego interlokutora. Jego poczucie humoru radosne, prześmiewcze i złośliwe pomaga zachować równowagę w świecie. Stańczyk parodiuje wypowiedzi króla, jego poufałość pozostaje bezkarna ze względu na jego profesję, która pozwalała, a nawet czasami nakazywała błaznowi mówić prawdę. Błazen to „tragikomiczny sobowtór" 12 króla, który wie, że jedyną jego bronią pozostaje śmiech, można powiedzieć, że tron przydaje mu wartości, a on dodaje tronowi świetności ${ }^{13}$. W dialogu postaci wykraczają poza swoje role i błazen w przestrzeni literackiej pozwala sobie na więcej niż zapewne miało to miejsce w rzeczywistości. Odbiorcy nie dziwi, że w tym satyrycznym i pesymistycznie skrojonym świecie na opak błazen jest mądrzejszy od króla, a król jest nazywany głupcem.

\section{R.: (...) Deludis, an iste}

Est cultus gentis, stulte, habitusque meae?

S.: Tu potius stultus, qui nescis tempore multo

Omnia mutari

(w. 23-26, s. 250).

${ }^{10}$ Interesujące i inspirujące dla tych interpretacji rozważania na temat satyry rzymskiej i jej decorum, vide Styka 1997: 98-109.

${ }^{11}$ „Etyczne decorum” to określenie J. Styki (1997: 102).

${ }^{12}$ Określenie Słowińskiego 1993: 117. Książka zawiera interesujące rozważania o błaznach w kulturze i literaturze dawnej Polski. Poza tym są w niej uwagi dotyczące opozycyjności i uzupełniania się postaci władcy i trefnisia w różnych epokach. Ważne uwagi ogólne na temat kondycji błazna, vide Kołakowski 1959: 65-85.

${ }^{13}$ Odwołuję się do słów Słowińskiego (1993: 118). 
Badacze podkreślali, że Stańczyk występuje w tym dialogu jako „laudator temporis acti”, choć sam dialog oparty na motywie ,powrotu” nie służy rozważaniom na temat przeszłości, ale ma cele aktualne; przez konfrontację „dobrej” przeszłości ze ,złą” teraźniejszością skupia się na współczesnych wydarzeniach politycznych i społeczno-obyczajowych ${ }^{14}$. Z dialogu wyłania się więc postać błazna-patrioty walczącego o naprawę kraju. Wpisana w tekst tendencja reformatorska to typowy znak rozpoznawczy późniejszej satyry staropolskiej, która służyła naganie i poprawie zepsutych obyczajów. Teoretycy szkolni XVII wieku wyróżniali dwa gatunki łączące się w satyrze: dirae - utwór potępiający zło i protrepticon - zachętę do dobrego postępowania ${ }^{15}$. Dialog postuluje naprawę społeczeństwa przez krytykę jego wad, ale wszystko to odbywa się w duchu moralistyki przybranej w parodystyczno-ironiczną szatę, a dydaktyka na potrzeby polemiki wykorzystuje uznane wartości i idee. Parodia jawi się w utworze jako forma wadząca się z tradycją, jednocześnie podkreślająca jej znaczenie i obalająca ją, a pozorny zabieg chwalenia w utworze przekształca się w wyrzut, fundując odbiorcy ironię antyfrastyczną ${ }^{16}$ - repetycja tego samego zjawiska przez Stańczyka zmienia jego znaczenie, odbiera mu powagę, którą miało w wypowiedzi Króla; tym samym zarzut komiczny uderza nawet mocniej niż surowa królewska krytyka:

\section{R.: (...) Quid autem}

A Turcis missas hic ego cerno togas?

Aut hosti turba ista favet, quia gaudet amictu

Illius, aut omen res habet ista malum.

S.: Immo forte bonum; spolia haec ex hoste feremus

Utemurque suis rebus et exuviis

(w. 35-40, s. 250)

Stańczyk rozmyślnie zbija argumenty Króla w dialogu, ale agonistyka i erystyka potrzebne są błaznowi nie po to, aby tryumfować nad rozmówcą, ale po to, aby pokazywać prawdziwy obraz rzeczywistości; rozumie to doskonale Król, który w swojej ostatniej wypowiedzi zalicza błazna do osób, które „mówią prawdę". Dialog można więc analizować w kategoriach retorycznej (albo komicznej?) tezy i antytezy. Utworowi politycznemu bliższa jest retoryczna lektura, w której teza i antyteza służą wnikliwej penetracji przedstawianej rzeczywistości historycznej, ścieraniu się poglądów w jej obrębie, przedstawianiu przyczyn i skutków pewnych zjawisk. W satyrze, wykorzystującej śmieszność i ironię, teza służy tylko temu, aby ją ,zabawnie” przeciwstawić antytezie. W dialogu

\footnotetext{
${ }^{14}$ Cf. rozważania na ten temat: Słowiński 1993: 306; Ziomek 1996: 88.

${ }^{15}$ Bogatsze refleksje na temat cech gatunkowych staropolskiej satyry, vide Michałowska 1974:149-151; Buchwald-Pelcowa 1998: 838-844.

${ }^{16}$ Ważkie rozważania na temat satyry, parodii i ironii, w tym również ironii antyfrastycznej, vide Hutcheon 1986: 331-350.
} 
Janickiego sytuacja się jednak komplikuje: poważno-śmieszny dialog oscyluje na granicy seria-ludicra, a antyteza okazuje się ,antytezą rzekomą" ${ }^{17}$, czyli tylko lekko (czytaj: błazeńsko) zmodyfikowaną tezą, i to zmodyfikowaną formalnie, a nie treściowo. Król słusznie gromi zastany stan rzeczy, a Stańczyk potwierdza wszystkie jego krytyczne wypowiedzi, wyolbrzymiając je w sposób komiczny i parodystyczny miejscami aż do absurdu.
R.: (...) Quid, qui a collo arrexere bicornem
Pannum Pannonico more supra usque caput?
S.: Si fugiant ventusque ruat posticus in illos, Hoc velo poterint accelerare fugam.
R.: Calcar praeterea adiungunt cubitale sonorum.
S.: Nempe locus pugnae si lapidosus erit,
Desilient ab equis strepitumque his calcibus edent Terrebuntque hostes, sicut arator aves
(w. 41-44, 51-54, s. 250, 252).

Morosophus z dialogu Janickiego nosi na sobie piętno antycznego Menipposa, głównego bohatera Rozmów zmarlych Lukiana z Samosat (II w. n.e.). Stańczyk - ironista, weredyk, znawca łaciny i żołnierz stał się godny rozmowy z królem na aktualne tematy, ale podobnie jak starożytny cynik pokazuje także ludzką obłudę, grę pozorów i fałszu, gonienie za tytułami i godnościami ${ }^{18}$. Dialog Janickiego jest rozmową zmarłego króla Władysława Jagiełły z żywym jeszcze wówczas Stańczykiem; mamy tu więc do czynienia z motywem ,powrotu" zmarłego, który prowadzi dialog z żywym. Utwór korespondowałby więc nie tylko z rozmowami zmarłych, lecz także z innymi Lukianowymi dialogami, takimi jak: Menippos albo wróżba z zaświatów i Ikaromenippos albo podróż napowietrzna, w których tytułowy bohater powraca $\mathrm{z}$ zaświatów na ziemię, aby skonfrontować zdobytą wiedzę z rzeczywistością. W tekstach antycznych i staropolskim dialogu odkrywamy aspekt satyryczny, ironię i przywoływany już fantastyczny motyw powrotu z zaświatów. Bezpośrednią inspiracją dla dialogu Janickiego nie musiał być sam Lukian, o czym pisał już w swoim opracowaniu Lucjan w Polsce Zygmunt Leśnodorski, ale twórcy europejscy epoki nowożytnej, których inspirowała tradycja antycznych dialogów. Są wśród nich Giovanni Pontano, Alberti, Maffeo Vegio, Erazm z Rotterdamu ${ }^{19}$. Dialog Janickiego, konfrontujący postaci o różnym statusie ontologicznym (zmarły - żywy) i społecznym (król - błazen) i traktujący o aktualnych problemach politycznych i obyczajowych, znajdzie swoją kontynuację w polskojęzycznych prozatorskich dialogach z okresu pierwszego bezkrólewia (anonimowa Rozmowa Lecha

\footnotetext{
${ }^{17}$ Interesujące uwagi o antytezie jako chwycie komicznym, vide Passi 1980: 173-180.

${ }^{18}$ Informacje o Stańczyku w literaturze i kulturze polskiej, vide Krzyżanowski 1958: 328-405; Słowiński 1993: 130-143; Wóycicki 1843: 168-179.

${ }^{19}$ Vide Leśnodorski 1933: 17; Marsh 1998: 54-75.
} 
z Piastem oraz dialogi: Rozmowa kruszwicka z 1573 r. i Rozmowa o odjeździe z Polski regis christianissimi Galliarum et Poloniae etc. Gaski ze św. Bartłomiejem Jana Dymitra Solikowskiego). Warto dodać, że podobny polemiczny i aktualny charakter będą miały osiemnastowieczne rozmowy zmarłych z okresu konfederacji barskiej i Sejmu Czteroletniego.

Można interpretować utwór Klemensa Janickiego za pomocą figury retorycznej jaką jest sermocinatio, która pozwalała wprowadzać cudze słowa, przytaczać rozmowy innych osób, pomagała też kreować i charakteryzować postaci. Ethopoia $=$ sermocinatio przyjmująca także formę dialogu służyła do pokazania ethosu postaci, czyli ich cech charakterystycznych i pomagała zachować stosowność (prepon) w zakresie charakteru i nastroju. Ethopoia, o czym wspomina Romuald Turasiewicz w swoim studium Od ethosu do ethopoii. Studia z antycznej terminologii krytyczno-literackiej u Dionizjusza z Halikarnasu, jako figura myśli (figura sententiae) miała także cel retoryczny, ponieważ pozwalała nadać wypowiedzi większą wagę, mówiły ją osoby o wysokim autorytecie moralnym, zasługujące na zaufanie ${ }^{20}$. Takie rozumienie etopei zbliża ją do prozopopei, która „obdarzała głosem” postaci zmarłych lub nieobecnych w chwili wygłaszania mowy ${ }^{21}$.

Dialog Janickiego imitujący rozmowę zmarłego z żywym nasuwa jeszcze inne skojarzenia genologiczne, oprócz wspominanych już w tym tekście antycznych rozmów zmarłych. Wiadomo, że co najmniej od XI wieku kontrastowano postacie żywe z trupami, zdolnymi do poruszania się i przemawiania, jak w poematach francuskich, niemieckich, włoskich i łacińskich, pokazujących spotkanie „trzech żywych i trzech umarłych”22. Piękni młodzieńcy spotykali zmarłych, którzy pokazywali im nicość ziemskiej egzystencji. W utworach zwanych ,sporami” (dialogus, interfactio, conflictus) dialog prowadzili Człowiek i Śmierć, najczęściej przybierająca postać rozkładającego się trupa z kosą. Janicki nie przejmuje tego średniowiecznego schematu fabularnego, ale być może dokonuje ciekawej kontaminacji średniowiecznego „,sporu” ze starożytną rozmową zmarłych. Wariacja jest intrygująca: zachowane zostaje tak ważne dla humanistów decorum, a dialogowy agon nie dotyczy już zbawienia duszy, ale aktualnych spraw polityczno-obyczajowych. Akcenty ideowe uległy oczywistemu przesunięciu.

Można powiedzieć, że dialog Janickiego jest w pełni samodzielny literacko i pozaliteracko, bogactwo znaczeń problemowych wpisanych w utwór

\footnotetext{
${ }^{20} \mathrm{Cf}$. Turasiewicz 1975: 91-96.

${ }^{21}$ Większość teoretyków skrupulatnie przestrzega różnicy pomiędzy prozopopeją (fictio personae) a etopeją (sermocinatio): prozopopeję ogranicza się do obiektów nieosobowych oraz osób zmarłych, a etopeję stosuje się do ludzi. Niektórzy krytycy, jak podaje Lausberg (2002: 454), zaliczają do prozopopei również osoby fikcyjne, a nawet żyjące, ale nieobecne w czasie wygłaszania mowy.

${ }^{22}$ Cechy charakterystyczne średniowiecznych dialogów, vide Michałowska 1993: 500-501.
} 
i towarzysząca temu gra z formą uczyniły (a może nawet predestynowały) dia$\log$ do bycia interesującą lekturą, mimo upływu setek lat. Oscylowanie między aktualnością i ponadczasowością, problematyką jednostkową i ogólnoludzką, mieszanie kategorii estetycznych dla efektu artystycznego pozwalają na nowe odczytania i interpretacje utworu. Dla Juliusza Nowaka-Dłużewskiego, autora opracowań o okolicznościowej poezji w dawnej Polsce, utwór Janickiego to przede wszystkim dialog polityczny ${ }^{23}$, dla Ludwika Ćwiklińskiego, badającego recepcję Lukiana w literaturze polskiej, Dialog przeciw różnorodności i zmienności polskich strojów jest rozmową zmarłych ${ }^{24}$, dla Pauliny Buchwald-Pelcowej utwór to świetny dialog satyryczny ${ }^{25}$. A więc czym jest elegijny dialog Klemensa Janickiego, związany z różnymi kręgami tradycji, bogaty w warstwie inwencyjnej, doskonały pod względem formalnym, zachowujący estetyczne i etyczne decorum? Zapewne hybrydą problemową i utworem synkretycznym w stosunku do tradycji literackiej i genologicznej. Założona wielowarstwowość na różnych poziomach utrudnia jednoznaczne określenie formy gatunkowej utworu, ale nie o to tak naprawdę chodziło w tych rozważaniach. Jak trafnie powiedział Janusz Pelc: „Tradycja zawsze jednak niemal, a przynajmniej na ogół u pisarzy wybitnych, jest zjawiskiem synkretycznym" ${ }^{26}$. Artyzm utworu zawiera się w tym, że poeta potrafił palące problemy polityczno-obyczajowe ubrać w poważnośmieszną szatę, która „łacniej” mogła spodobać się odbiorcy i uczynić gorzkie prawdy możliwymi do przełknięcia.

\section{BIBLIOGRAFIA}

Buchwald-Pelcowa 1998: P. Buchwald-Pelcowa, Satyra, [w:] T. Michałowska (red.), Stownik literatury staropolskiej. Średniowiecze, Renesans. Barok, Wrocław-Warszawa-Kraków 1998, $838-844$.

Cytowska 1993: M. Cytowska, Obraz Polski w poezji polsko-łacińskiej XVI wieku, „Odrodzenie i Reformacja Polsce" 37 (1993), 59-68.

Ćwikliński 1934: L. Ćwikliński, Przyczynki do historii poezji polsko-łacińskiej w XVI wieku, Poznań 1934.

Głowiński 1978: M. Głowiński, Lektura dzieła a wiedza historyczna, [w:] Z. Stefanowska i J. Sławiński (red.), Dzieło literackie jako źródło historyczne, Warszawa 1978, 94-113.

Hutcheon 1986: L. Hutcheon, Ironia, satyra, parodia - o ironii w ujęciu pragmatycznym, tłum. K. Górska, „Pamiętnik Literacki” 78 (1986), 331-350.

Janicki 1966: K. Janicki, Carmina. Dzieła wszystkie, wyd. J. Krókowski, thum. E. Jędrkiewicz, wstęp, komentarz J. Mosdorf, Wrocław-Warszawa-Kraków 1966.

Kołakowski 1959: L. Kołakowski, Kapłan i błazen. Rozważania o teologicznym dziedzictwie wspótczesnego myślenia, „Twórczość” 60 (1959), 65-85.

\footnotetext{
${ }^{23}$ Nowak-Dłużewski 1966: 101-103.

${ }^{24}$ Ćwikliński 1933: 17.

${ }^{25}$ Buchwald-Pelcowa 1998: 841.

${ }^{26}$ Pelc 1984: 195.
} 
Krzyżanowski 1954: J. Krzyżanowski, Mikołaja Reja „Krótka rozprawa” na tle swoich czasów, Warszawa 1954.

Krzyżanowski 1958: J. Krzyżanowski, W wieku Reja i Stańczyka. Szkice z dziejów odrodzenia w Polsce, Warszawa 1958.

Lausberg 2002: H. Lausberg, Retoryka literacka. Podstawy wiedzy o literaturze, przekł., oprac. i wstęp A. Gorzkowski, Bydgoszcz 2002.

Leśnodorski 1933: Z. Leśnodorski, Lucjan w Polsce, Kraków 1933.

Marsh 1998: D. Marsh, Lucian and the Latins. Humor and Humanism in the Early Renaissance, Michigen 1998.

Michałowska 1974: T. Michałowska, Staropolska teoria genologiczna, Wrocław 1974.

Michałowska 1996: T. Michałowska, Średniowiecze, Warszawa 1996.

Nowak-Dłużewski 1966: J. Nowak-Dłużewski, Okolicznościowa poezja polityczna w Polsce. Czasy zygmuntowskie, Warszawa 1966.

Pajewski 1997: J. Pajewski, Buńczuk i koncerz. Z dziejów wojen polsko-tureckich, Poznań 1997.

Passi 1980: I. Passi, Powaga śmieszności, tłum. K. Minczewa-Gospodarek, wstęp E. Borowiecka, Warszawa 1980.

Pelc 1984: J. Pelc, Europejskość i polskość literatury naszego renesansu, Warszawa 1984.

Słowiński 1993: M. Słowiński, Błazen. Dzieje postaci i motywu, Warszawa 1993.

Styka 1997: J. Styka, Estetyka stosowności (decorum) w literaturze rzymskiej, Kraków 1997.

Turasiewicz 1975: R. Turasiewicz, Od ethosu do ethopoii. Studia z antycznej terminologii krytyczno-literackiej u Dionizjusza z Halikarnasu, Kraków 1975.

Wóycicki 1843: K.L. Wóycicki, Obrazy starodawne, t. 1, Warszawa 1843.

Ziomek 1996: J. Ziomek, Renesans, Warszawa 1996.

\section{A SATIRE, A DIALOGUE OF THE DEAD OR POLITICAL DIALOGUE? ABOUT THE GENRE FORM OF A LITERARY PIECE BY KLEMENS JANICKI ENITLED IN POLONICI VESTITUS VARIETATEM ET INCONSTANTIAM DIALOGUS}

\section{Sum mary}

The dialogue was written by Klemens Janicki after the Turks conquered Buda, thus, it was a reaction to political events of the time. It combines the political issues and a satire of manners and social life, criticising the affinity of the Poles to affluence and profusion and their adherence to foreign trends. The poet used the form of a dialogue of the dead, which was popular in the Renaissance and which was applied in subsequent epochs for the purpose of polemics and satires. The elegiac dialogue by Klemens Janicki features its syncretic nature both at the level of the problems discussed and at the level of the adopted form. 